\title{
Effect of Sowing Dates on Growth and Yield of Foxtail Millet (Setaria italica L.) Varieties
}

\author{
B. Srikanya*, P. Revathi, M. Malla Reddy and K. Chandrashaker
}

Department of Agronomy, College of Agriculture, Professor Jayashanker Telangana State Agricultural University, Rajendranagar, Hyderabad-030, Telangana State, India

*Corresponding author

\begin{tabular}{|c|c|}
\hline & B S T R A T \\
\hline $\begin{array}{l}\text { K e y w o r d s } \\
\text { Foxtail millet, Varieties, } \\
\text { Dates of sowing, Growth, } \\
\text { Yield, Economics }\end{array}$ & \multirow{3}{*}{$\begin{array}{l}\text { A field experiment was conducted during Kharif, } 2017 \text { at Regional Agricultural Research } \\
\text { Station, Jagtial with three varieties (SiA } 3156, \mathrm{SiA} 3085 \text { and Suryanandi) in combination } \\
\text { with four dates of sowing }\left(10^{\text {th }}, 20^{\text {th }} 30^{\text {th }} \text { August and } 10^{\text {th }} \text { September). The results revealed }\right. \\
\text { that the variety } \mathrm{SiA} 3085 \text { recorded significantly higher stature of growth, yield attributes } \\
\text { and yield. The above parameters were at their lower level with the variety Suryanandi. The } \\
\text { crop sown on } 30^{\text {th }} \text { August performed significantly higher stature of plant growth } \\
\text { parameters; yield attributes and yields, while they were found to be at their lower level } \\
\text { when sown on } 10^{\text {th }} \text { September. The results concluded that sowing of foxtail millet variety } \\
\text { SiA } 3085 \text { up to last fort night of August was profitable to the farmers in sandy loam soils } \\
\text { of Northern Agro-climatic zone of Telangana. }\end{array}$} \\
\hline Article Info & \\
\hline $\begin{array}{l}\text { Accepted: } \\
30 \text { March } 2020 \\
\text { Available Online: } \\
10 \text { April } 2020\end{array}$ & \\
\hline
\end{tabular}

\section{Introduction}

Foxtail millet or Italian millet (Setaria italica L.) is one of the oldest and second most cultivated small millets for food and fodder. It is known for its drought tolerance (Cheng and Liu, 2003) and can withstand severe moisture stress and also suited to wide range of soil conditions. Foxtail millet has an excellent nutritional profile and is miles ahead of rice and wheat in terms of protein, fibre, minerals and vitamins. It is rich in dietary fibre $(6.7 \%)$, protein $(11 \%)$, and low in fat (4\%). Unlike rice, foxtail millet releases glucose steadily without affecting the metabolism of human body. Hence, it is recognized as diabetic food. As the consumption of foxtail millet is increasing day by day particularly by the people suffering with diabetes, there is an increasing demand for foxtail millet (Hariprasanna, 2006).

In India foxtail millet is grown in an area of 98,000 ha producing about 56,000 tons of grain with an average productivity of $565 \mathrm{~kg}$ $\mathrm{ha}^{-1}$ (Department of Agriculture and Cooperation, Ministry of Agriculture, GOI, 2014). Andhra Pradesh, Karnataka, Tamilnadu are the major foxtail millet growing states contributing about $90 \%$ of the total area under cultivation. Combined Andhra Pradesh alone contributed for about $79 \%$ of the total area under foxtail millet. In Telangana State, foxtail millet is mostly grown in Mahbubnagar and Rangareddy districts (Hariprasanna, 2006). 
The yield potential of foxtail millet is very low because of conventional cultivation of low yielding cultivars, inadequate application of fertilizers and lack of good management practices. New short duration varieties of SIA 3085 and SIA 3088 are becoming popular. They have a yield potential of $20-25 \mathrm{q}^{-} \mathrm{ha}^{-}$ ${ }^{1}$ (AICSMIP, 2015).There is a good scope for increase in area under foxtail millet because of the new opportunities and new varieties.

During the present days of climatic change, high energy farming is slowly replaced with low energy traditional farming with climatic resilient crops like small millets for conservation and to aid in making sound and stable management under increasing evidence of less seasonal rainfall, increase in temperature and frequent occurrence of extreme weather events. Under such situations foxtail millet is best suited as it is of short duration, known for its drought tolerance and can withstand severe moisture stress and also suited to wide range of soil conditions with high energy use efficiency. In the present context of climate change and recurrent aberrant weather conditions, foxtail millet can be grown as a contingent crop (PJTSAU, 2015-16).

Experimental evidence regarding the optimum date of sowing for improved foxtail millet varieties under rainfed conditions is lacking for Northern Agro climatic zone of Telangana. Hence, promising foxtail millet varieties were tested for their response to dates of sowing to evaluate their yield potentiality.

\section{Materials and Methods}

In order to study the effect of sowing dates on growth, yield and economics of foxtail millet varieties, an experiment was conducted during kharif, 2017 at Regional Agricultural Research Station, situated in the same campus of Agricultural College, PJTSAU, Polasa, Jagtial,
Telangana State. The experiment was laid out in Randomized block design with factorial concept (FRBD) and it was replicated thrice. Three varieties viz., SiA 3156, SiA 3085 and Suryanandi in combination with four dates of sowing viz., $10^{\text {th }}, 20^{\text {th }} 30^{\text {th }}$ August and $10^{\text {th }}$ September was adopted, thus a total of 12 treatments were imposed. The soil of the experiment site was sandy loam in texture, having slightly alkaline $(\mathrm{pH} 8.21)$, normal in salinity (EC $0.159 \mathrm{~d} \mathrm{Sm}^{-1}$ ), medium in organic carbon content $(0.85 \%)$, low in available $\mathrm{N}$ $\left(220 \mathrm{~kg} \mathrm{ha}^{-1}\right)$, high in available phosphorus $\left(28.23 \mathrm{~kg} \mathrm{ha}^{-1}\right)$ and medium in available potassium (249.0 $\left.\mathrm{kg} \mathrm{ha}{ }^{-1}\right)$. Recommended dose of $\mathrm{N}, \mathrm{P}$ and $\mathrm{K}$ (40-30-0 kg ha ${ }^{-1} \mathrm{~N}, \mathrm{P}_{2} \mathrm{O}_{5}$ and $\mathrm{K}_{2} \mathrm{O}$ ) was applied to all plots in the form of Urea and SSP. The crop was sown in lines at $30 \times 10 \mathrm{~cm}$ spacing. The crop was sown on $10^{\text {th }}, 20^{\text {th }}, 30^{\text {th }}$ August and $10^{\text {th }}$ September, 2017. The time of harvesting varied from 7590 days after sowing, depending upon the varietal duration.

\section{Results and Discussion}

\section{Performance of varieties under different dates of sowing}

Final plant population of foxtail millet was significantly influenced by different varieties as well as sowing dates, while their interaction effect was not significant (Table 1).

The final plant population of 31,29 and $28 \mathrm{~m}^{-2}$ was registered with the variety SIA $3085\left(\mathrm{C}_{2}\right)$, SIA $3156\left(\mathrm{C}_{1}\right)$ and Suryanandi $\left(\mathrm{C}_{3}\right)$, respectively. Similarly final plant population of $32,31,28$ and $27 \mathrm{~m}^{-2}$ recorded on $\mathrm{D}_{3}, \mathrm{D}_{2}$, $\mathrm{D}_{1}$ and $\mathrm{D}_{4}$ (Sowing on $30^{\text {th }}, 20^{\text {th }}, 10^{\text {th }}$ August and $10^{\text {th }}$ September) respectively.

Variety Suryanandi showed decreased final plant stand as compared to $\mathrm{SiA} 3085$ and $\mathrm{SiA}$ 3156, indicating increased mortality of seedling on $10^{\text {th }}$ August due to heavy rainfall, 
more humidity and excessive wet soil condition from sowing to tillering stage and on $10^{\text {th }}$ September less rainfall coupled with extreme temperature and low soil moisture caused less plant stand per metre square area. These results are in line with the findings of Mahendra Singh et al., (1975)

Plant height recorded at harvest was significantly influenced by different varieties and dates of sowing, whereas the interaction between varieties and sowing dates was found to be non-significant.

Significantly superior plant height $(120.4 \mathrm{~cm})$ was recorded with $\mathrm{SiA} 3156\left(\mathrm{C}_{1}\right)$ which was on par with $\mathrm{SiA} 3085\left(\mathrm{C}_{2}\right)$. The variety Suryanandi $\left(\mathrm{C}_{3}\right)$ produced the shortest plant height $(105.4 \mathrm{~cm})$. The difference in plant height among the varieties might be due to the variation in their genetic character and inter nodal length. The above results are in confirmity with the findings of Navya Jyothi et al., (2015).

Similarly, significantly highest plant height $\left(120.7 \mathrm{~cm}\right.$ ) was recorded with $\mathrm{D}_{3}$ (sowing on $30^{\text {th }}$ August), which was significantly on par with $\mathrm{D}_{2}$ (sowing on $20^{\text {th }}$ August) which in turn comparable with $\mathrm{D}_{1}$ (sowing on $10^{\text {th }}$ August). While the shorter plants $(108.9 \mathrm{~cm})$ were registered on $\mathrm{D}_{4}$ (sowing on $10^{\text {th }}$ September). Similar findings were in line with the findings of Umashanker Lal (1982) and Dubey et al., (1993).

The total number of tillers $\mathrm{m}^{-2}$ recorded at harvest was significantly influenced by different varieties and dates of sowing. While the interaction between varieties and sowing dates was found to be non-significant (Table 1).

Significantly superior number of tillers $\mathrm{m}^{-2}$ (93) was recorded with $\mathrm{SiA} 3085 \quad\left(\mathrm{C}_{2}\right)$ followed by $\mathrm{SiA} 3156 \quad\left(\mathrm{C}_{1}\right) \quad(90)$ and significantly inferior number of tillers $\mathrm{m}^{-2}(79)$ was obtained with the variety Suryanandi $\left(\mathrm{C}_{3}\right)$. The above results are in conformity with the findings of Navya Jyothi et al., (2015).

The highest number of tillers $\mathrm{m}^{-2}$ (100) was recorded with $\mathrm{D}_{3}$ (sowing on $30^{\text {th }}$ August), which was comparable (97) with $\mathrm{D}_{2}$ (sowing on $20^{\text {th }}$ August). Similarily highest number of tillers $\mathrm{m}^{-2}$ (81) recorded with $\mathrm{D}_{1}$ (sowing on $10^{\text {th }}$ August) was comparable with $\mathrm{D}_{4}$ (sowing on $10^{\text {th }}$ September) (72).

Dry matter production of foxtail millet showed an increasing trend with advance in age of the crop up to maturity (Table 1). Dry matter production of foxtail millet varied significantly due to varieties and dates of sowing, while the interaction effect was found to be non-significant.

Among the varieties significantly superior dry matter $\left(354.1 \mathrm{~g} \mathrm{~m}^{-2}\right)$ was accumulated with the variety $\mathrm{SiA} 3085\left(\mathrm{C}_{2}\right)$ followed by $\mathrm{SiA} 3156$ $\left(\mathrm{C}_{1}\right)\left(324.8 \mathrm{~g} \mathrm{~m}^{-2}\right)$ and Suryanandi $\left(\mathrm{C}_{3}\right)(283.8$ $\mathrm{g} \mathrm{m}^{-2}$ ) respectively. This could be mainly attributed to increase in plant height and leaf area due to their genetic makeup. The increase in the assimilatory surface area per plant might have caused an increase in its biomass, which ultimately lead to the accumulation of a large quantity of photo assimilates. This is in accordance with the results reported by Intodia (1994), Saini and Thakur (1997) and Raghavendra and Halikatti (1998).

Among the dates of sowing significantly highest dry matter $\left(356.0 \mathrm{~g} \mathrm{~m}^{-2}\right)$ was recorded with $\mathrm{D}_{3}$ (sowing on $30^{\text {th }}$ August) which was on par (349.3 $\mathrm{g} \mathrm{m}^{-2}$ ) with $\mathrm{D}_{2}$ (sowing on $20^{\text {th }}$ August) and it was at par $\left(347.4 \mathrm{~g} \mathrm{~m}^{-2}\right)$ with $\mathrm{D}_{1}$ sowing date (sowing on $10^{\text {th }}$ August). These treatments significantly superior (231.0 $\mathrm{g} \mathrm{m}^{-2}$ ) over $\mathrm{D}_{4}$ (sowing on $10^{\text {th }}$ September). The highest dry matter production recorded on $20^{\text {th }}$ and $30^{\text {th }}$ August could be attributed to the 
cumulative effect of increased plant height, maximum number of tiller production and the crop had an opportunity of longer growth period with sufficient light, temperature, relative humidity, bright sunshine hours coupled with optimum day length which might have increased photosynthesis, in turn, dry matter production and yield. On the other hand delay in sowing during $10^{\text {th }}$ September resulted in negetative phase coinciding with short day periods resulting in lower biomass accumulation and in turn lower yield. Similar findings were observed with Revathi et al., (2017).

Number of panicles $\mathrm{m}^{-2}$ at harvest was significantly influenced by varieties and dates of sowing. While, the interaction between varieties and dates of sowing was found nonsignificant (Table 1)

The highest number of panicles $\mathrm{m}^{-2}$ (86.7) was recorded with the variety $\mathrm{SiA} 3085$ which was significantly on par with SiA 3156 (83 panicles $\mathrm{m}^{-2}$ ) and both of these varieties were significantly superior to that of the Suryanandi (75.7 panicles $\mathrm{m}^{2}$ ). This might be due to the genetic potential of the variety to produce more number of tillers $\mathrm{m}^{-2}$ and then converted to more number of productive tillers $\mathrm{m}^{-2}$.

The highest number of panicles $\mathrm{m}^{-2}$ (95.3) was recorded with $\mathrm{D}_{3}$ (sowing on $30^{\text {th }}$ August) which was significantly on par (90.9) with $\mathrm{D}_{2}$ (sowing on $20^{\text {th }}$ August). Next best treatment 75.1 panicles $\mathrm{m}^{-2}$ recorded with $\mathrm{D}_{1}$ (sowing on $10^{\text {th }}$ August) which was at par (66) with $\mathrm{D}_{4}$ (sowing on $10^{\text {th }}$ September). Crop sown on $\mathrm{D}_{3}$ received well distribution of rain fall and bright sunshine hours might have contributed in getting good yields. Though the earliest crop received good amount of rainfall less productive tillers $\mathrm{m}^{-2}$ were produced due to more humidity in atmosphere as well as excess soil moisture caused lodging of crop, more prone to disease infestation and seed mortality. The late planted crop is subjected to relatively lesser time span available for plant growth and development. Our findings confirm the results of Umashanker Lal (1982), Dubey et al., (1993) and Upadhayay et al., (2001).

The panicle length of foxtail millet was significantly influenced by different varieties and dates of sowing, while the interaction effect was non-significant (Table 2).

The variety SIA $3085 \quad\left(\mathrm{C}_{2}\right)$ recorded significantly superior panicle length $(20.5$ $\mathrm{cm})$. The next best variety is SIA $3156\left(\mathrm{C}_{1}\right)$ with panicle length of $(17.6 \mathrm{~cm})$ and it was at par $(16.3 \mathrm{~cm})$ with Suryandi $\left(\mathrm{C}_{3}\right)$. This might be due to the genetic potential of the variety in deciding the length of the panicle and in better partitioning of assimilates from source to sink. Similar results were obtained by Intodia (1994) and Saini and Negi (1996) and Navya Jyothi et al., (2015).

Significantly on par ear head length of (20.5 and $19.7 \mathrm{~cm}$ ) recorded on sowing dates of $D_{3}$ (Sowing on $30^{\text {th }}$ August) and $\mathrm{D}_{2}$ (Sowing on $20^{\text {th }}$ August) respectively. Followed by higher ear head length of $(17.2 \mathrm{~cm})$ recorded in $D_{1}$ (Sowing on $10^{\text {th }}$ August) which was statistically nearer to $\mathrm{D}_{4}$ (sowing on $10^{\text {th }}$ September).

Number of grains ear head ${ }^{-1}$ of foxtail millet was significantly influenced by different varieties and dates of sowing, while the interaction effect was non-significant (Table 2).

Among varieties tested, the highest number of filled grains ear head ${ }^{-1}$ (1386) was obtained with the variety SIA $3085\left(\mathrm{C}_{2}\right)$ which was comparable (1255) with that of variety SIA $3156\left(\mathrm{C}_{1}\right)$.Significantly lowest number of filled grains ear head ${ }^{-1}(898)$ was produced by the variety Suryanandi $\left(\mathrm{C}_{3}\right)$. 
Table.1 Effect of sowing dates on growth parameters foxtail millet varieties

\begin{tabular}{|c|c|c|c|c|c|}
\hline Treatment & $\begin{array}{c}\text { Final plant } \\
\text { population } \\
\left(\mathrm{m}^{-2}\right)\end{array}$ & $\begin{array}{l}\text { Plant } \\
\text { height } \\
(\mathrm{cm})\end{array}$ & $\begin{array}{c}\text { No. of tillers } \\
\mathbf{m}^{-2}\end{array}$ & $\begin{array}{l}\text { Dry matter } \\
\text { accumulation } \\
\left(\mathrm{g} \mathrm{m}^{-2}\right)\end{array}$ & $\begin{array}{c}\text { No. of } \\
\text { panicles } \\
\mathbf{m}^{-2}\end{array}$ \\
\hline \multicolumn{6}{|l|}{ Varieties } \\
\hline C1: SiA 3156 & 29 & 120.4 & 90 & 324.8 & 83.0 \\
\hline C2: SiA 3085 & 31 & 117.5 & 93 & 354.1 & 86.7 \\
\hline C3: Suryanandi & 28 & 105.4 & 79 & 283.8 & 75.7 \\
\hline SEm \pm & 1.03 & 1.66 & 2.68 & 11.43 & 2.49 \\
\hline $\mathrm{CD}(\mathrm{P}=0.05)$ & 3.0 & 4.9 & 7.9 & 33.7 & 7.4 \\
\hline \multicolumn{6}{|l|}{ Sowing dates } \\
\hline $\mathrm{S}_{1}: 10^{\text {th }}$ August & 28 & 111.3 & 81 & 347.4 & 75.1 \\
\hline $\mathrm{S}_{2}: 20^{\text {th }}$ August & 31 & 115.6 & 97 & 349.3 & 90.9 \\
\hline $\mathrm{S}_{3}: 30^{\text {th }}$ August & 32 & 120.7 & 100 & 356.0 & 95.3 \\
\hline $\mathrm{S}_{4}: 10^{\text {th }}$ September & 27 & 108.9 & 72 & 231.0 & 66.0 \\
\hline SEm \pm & 1.18 & 1.91 & 3.09 & 13.20 & 2.88 \\
\hline $\mathrm{CD}(\mathrm{P}=0.05)$ & 3.5 & 5.6 & 9.1 & 38.9 & 8.5 \\
\hline \multicolumn{6}{|l|}{ Interaction } \\
\hline $\mathrm{SEm} \pm$ & 2.05 & 3.32 & 5.36 & 22.86 & 4.98 \\
\hline $\mathrm{CD}(\mathrm{P}=0.05)$ & NS & NS & NS & NS & NS \\
\hline $\mathrm{CV}(\%)$ & 12.6 & 5.39 & 11.3 & 13.3 & 11.3 \\
\hline
\end{tabular}

Table.2 Effect of sowing dates on yield attributes and yields of foxtail millet varieties

\begin{tabular}{|c|c|c|c|c|c|c|}
\hline Treatment & $\begin{array}{l}\text { Length of } \\
\text { ear head } \\
\text { (cm) }\end{array}$ & $\begin{array}{c}\text { No. of } \\
\text { grains per } \\
\text { ear head }\end{array}$ & $\begin{array}{c}\text { Test } \\
\text { weight }(\mathrm{g})\end{array}$ & $\begin{array}{c}\text { Grain } \\
\text { yield } \\
\left(\mathrm{kg} \mathrm{ha}^{-1}\right)\end{array}$ & $\begin{array}{c}\text { Stover } \\
\text { yield } \\
\left(\mathrm{kg} \mathrm{ha}^{-1}\right)\end{array}$ & $\begin{array}{l}\text { B: } C \\
\text { ratio }\end{array}$ \\
\hline \multicolumn{7}{|l|}{ Varieties } \\
\hline C1: SiA 3156 & 17.6 & 1255 & 2.7 & 1151 & 2318 & 1.67 \\
\hline C2: SiA 3085 & 20.5 & 1386 & 2.9 & 1317 & 2584 & 1.95 \\
\hline C3: Suryanandi & 16.3 & 898 & 2.5 & 951 & 2213 & 1.42 \\
\hline SEm \pm & 0.71 & 38.18 & 0.09 & 59.87 & 98.52 & 0.09 \\
\hline $\mathrm{CD}(\mathrm{P}=0.05)$ & 2.1 & 112.0 & 0.9 & 175.7 & 289.0 & 0.3 \\
\hline \multicolumn{7}{|l|}{ Sowing dates } \\
\hline $\mathrm{S}_{1}: 10^{\text {th }}$ August & 17.2 & 1201 & 2.6 & 1063 & 2384 & 1.54 \\
\hline $\mathrm{S}_{2}: 20^{\text {th }}$ August & 19.7 & 1273 & 2.8 & 1228 & 2663 & 1.83 \\
\hline $\mathrm{S}_{3}: 30^{\text {th }}$ August & 20.5 & 1479 & 3.0 & 1300 & 2848 & 1.94 \\
\hline $\mathrm{S}_{4}: 10^{\text {th }}$ September & 15.1 & 765 & 2.4 & 968 & 1591 & 1.42 \\
\hline SEm \pm & 0.82 & 44.11 & 0.11 & 69.13 & 113.76 & 0.10 \\
\hline $\mathrm{CD}(\mathrm{P}=0.05)$ & 2.4 & 129.3 & 0.3 & 202.8 & 333.6 & 0.3 \\
\hline \multicolumn{7}{|l|}{ Interaction } \\
\hline SEm \pm & 1.42 & 76.41 & 0.19 & 119.75 & 197.05 & 0.18 \\
\hline $\mathrm{CD}(\mathrm{P}=0.05)$ & NS & NS & NS & NS & NS & NS \\
\hline CV (\%) & 13.9 & 11.2 & 9.7 & 18.2 & 14.4 & 12.3 \\
\hline
\end{tabular}


Higher number of filled grains panicle ${ }^{-1}$ with SIA $3085\left(\mathrm{C}_{2}\right)$ might be due to efficient translocation of photosynthates from source to the sink and also the genetic potential of variety. This is in the accordance with the results reported by Divya and Maurya (2013) and Navya Jyothi et al., (2015).

Among different sowing dates, the significantly highest number of filled grains ear head ${ }^{-1}$ (1479) was recorded on $\mathrm{D}_{3}$ (sowing on $30^{\text {th }}$ August) followed by (1273 grains ear head $^{-1}$ ) on $\mathrm{D}_{2}$ (sowing on $20^{\text {th }}$ August) which was comparable with (1201 grains ear head ${ }^{-1}$ ) on $\mathrm{D}_{1}$ (sowing on $10^{\text {th }}$ August). Significantly inferior number of filled grains ear head ${ }^{-1}$ (765) was recorded with $\mathrm{D}_{4}$ (sowing on $10^{\text {th }}$ September). The experiment results revealed that highest number of grains ear head ${ }^{-1}$ was recorded on last fort night of August. This may be due to optimum date of sowing as contingent crop and with optimum plant population provides favourable micro climate to crop for effective utilization of available moisture and nutrients leading to better partitioning of photosynthates to reproductive parts might be the reason of getting higher yield attributes. These results are in line with the findings of Anitha et al., (2015).

Test weight of foxtail millet was found to be influenced by different varieties and dates of sowing while the interaction effect was nonsignificant (Table 2).

Among the varieties tested, test weight of (2.9 g) was obtained with the variety $\mathrm{SiA} 3085$ $\left(\mathrm{C}_{2}\right)$ and $(2.7 \mathrm{~g})$ with $\mathrm{SiA} 3156\left(\mathrm{C}_{1}\right)$ they were significantly on par and in turn $\operatorname{SiA} 3156\left(\mathrm{C}_{1}\right)$ is at par with test weight of Suryanandi $\left(C_{3}\right)$ $(2.5 \mathrm{~g})$.

Among different sowing dates, the significantly highest test weight $(3.0 \mathrm{~g})$ was recorded on $\mathrm{D}_{3}$ (sowing on $30^{\text {th }}$ August) which was comparable $(2.8 \mathrm{~g})$ with $\mathrm{D}_{2}$ (sowing on $20^{\text {th }}$ August). Significantly inferior test weight was recorded in $D_{4}$ (sowing on $10^{\text {th }}$ September).

Crop sown on $2^{\text {nd }}$ fort night of August received good amount of rainfall with equal distribution and bright sunshine hours which might have helped better growth of plant, higher production of dry matter which ultimately increased the partitioning of dry matter to ear head and its development. These findings were in line with the findings of Upadhyay et al., (2001), Anitha et al., (2015) and Prathima et al., (2015).

The grain yield and stover yield of foxtail millet was significantly influenced by the varieties and dates of sowing, while the interaction effect was not statistically traceable (Table 2).

The significantly highest grain yield $(1317 \mathrm{~kg}$ $\mathrm{ha}^{-1}$ ) was produced by the variety SIA 3085 $\left(\mathrm{C}_{2}\right)$ which was on par with the yield $(1151 \mathrm{~kg}$ $\left.\mathrm{ha}^{-1}\right)$ produced by the variety SIA $3156\left(\mathrm{C}_{1}\right)$ and both of these varieties were significantly superior to that of the variety Suryanandi $\left(\mathrm{C}_{3}\right)$. In turn Suryanandi $\left(\mathrm{C}_{3}\right)$ recorded significantly the lowest grain yield $(951 \mathrm{~kg}$ $\left.\mathrm{ha}^{-1}\right)$. Difference in yields among the varieties can be attributed to their genetic potentiality to utilize and translocate photosynthates from source to sink (Anitha et al., 2015). Dhagat et al., (1977) also reported that in Itallian millet (Korra) grain yield was positively correlated with length, weight and grain yield of the main ear head and harvest index. The results were in confirmity with the findings of Munirathnam et al., (2006), Divya and Maurya (2013), Revathi et al., (2015) and Navya Jyothi et al., (2015).

The significantly highest grain yield $(1300 \mathrm{~kg}$ $\mathrm{ha}^{-1}$ ) was recorded with $\mathrm{D}_{3}$ (sowing on $30^{\text {th }}$ August) followed by grain yield of $(1228 \mathrm{~kg}$ $\mathrm{ha}^{-1}$ ) in $\mathrm{D}_{2}$ (sowing on $20^{\text {th }}$ August) and it was 
on par with the grain yield of (1063 kg ha $\left.{ }^{-1}\right)$ in $\mathrm{D}_{1}$ (sowing on $10^{\text {th }}$ August). Significantly inferior grain yield (968 kg ha ${ }^{-1}$ ) was recorded with $\mathrm{D}_{4}$ (sowing on $10^{\text {th }}$ September).

Among the varieties tested, the highest straw yield $\left(2584 \mathrm{~kg} \mathrm{ha}^{-1}\right)$ was obtained with the variety $\mathrm{SiA} 3085\left(\mathrm{C}_{2}\right)$ and it was on par with the stover yield of $\left(2318 \mathrm{~kg} \mathrm{ha}^{-1}\right)$ with $\mathrm{SiA}$ $3156\left(\mathrm{C}_{1}\right)$ and in turn $\mathrm{SiA} 3156\left(\mathrm{C}_{1}\right)$ is at par with stover yield of $\left(2213 \mathrm{~kg} \mathrm{ha}^{-1}\right)$ recorded with $\mathrm{SiA} 3156\left(\mathrm{C}_{1}\right)$. Genetic makeup of the variety and environmental conditions also contributed to more dry matter production which ultimately increases the stover yield. The similar results were reported by Munirathnam et al., (2006) Divya and Maurya (2013) and Navya Jyothi et al., (2015).

The significantly highest stover yield (2848 $\mathrm{kg} \mathrm{ha}{ }^{-1}$ ) was recorded with $\mathrm{D}_{3}$ (sowing on $30^{\text {th }}$ August) and was statistically comparable with $\mathrm{D}_{2}$ yield (2663 $\mathrm{kg} \mathrm{ha}{ }^{-1}$ ) (sowing on $20^{\text {th }}$ August) and in turn $\mathrm{D}_{2}$ was on par with $\mathrm{D}_{1}$ (sowing on $10^{\text {th }}$ August) with that of stover yield $\left(2384 \mathrm{~kg} \mathrm{ha}^{-1}\right)$. Significantly inferior stover yield (1591 kg ha-1) was recorded with $\mathrm{D}_{4}$ (sowing on $10^{\text {th }}$ September).

The crop sown in $\mathrm{D}_{3}\left(30^{\text {th }}\right.$ August) showed significantly higher grain and stover yield. This may be due to good amount and equal distribution of rain fall from sowing to vegetative stage, bright sunshine hours which might have contributed in getting good yields. In first fortnight of August planting $\left(D_{1}\right)$ less yield was observed than second and third fortnight. This is because high rain fall intensity, lower temperature and higher humidity from flowering to reproductive stage caused more disease infestation, shedding of inflorescence, poor grain setting which finally reduced the grain productivity (Mahendra Singh et al., 1975). Late sown crop experienced extreme moisture stress during seedling and ear head emergence period which drastically reduced the final plant stand (Mahendra Singh et al., 1975) and partitioning of dry matter to ear head and its development could not be received even with sufficient moisture conditions later on (Prathima et al., 2015). Thus, sowing of foxtail millet beyond or before its optimum period caused reduction of grain yield. Our findings are in line with the results of Dubey et al., (1993) and Prathima et al., (2015)

Benefit-cost ratio of foxtail millet was significantly influenced by varieties and dates of sowing while the interaction was not statistically traceable (Table 2).

The highest benefit-cost ratio (1.94) was recorded with the variety SIA $3085 \quad\left(\mathrm{C}_{2}\right)$ which was however comparable (1.83) with that of variety SIA $3156\left(\mathrm{C}_{1}\right)$ and both of these varieties were significantly superior to the variety Suryanandi $\left(\mathrm{C}_{3}\right)$ (1.54). Higher grain and straw yields and net returns obtained with variety SIA $3085\left(\mathrm{C}_{2}\right)$ might be responsible for higher benefit-cost ratio. The present findings corroborates with that of Subramanian and Ganesaraja (1992), Munirathnam et al., (2006) and Navya Jyothi et al., (2015).

The significantly highest Benefit-cost ratio (1.94) was recorded with $\mathrm{D}_{3}$ (sowing on $30^{\text {th }}$ August) and it was statistically comparable with B: C ratio of 1.83 recorded in $\mathrm{D}_{2}$ (sowing on $20^{\text {th }}$ August) followed by B: C ratio of 1.54 in $\mathrm{D}_{1}$ (sowing on $10^{\text {th }}$ August) and it was on par with $\mathrm{D}_{4}$ (sowing on $10^{\text {th }}$ September). These results are in line with the findings of Upadhay et al., (2001).

From this study, it can be concluded that higher productivity of foxtail millet obtained with cultivation of varieties $\mathrm{SiA} 3085$ and $\mathrm{SiA}$ 3156 were suitable when sown up to $30^{\text {th }}$ August as contingent crop. 


\section{References}

Anitha, D., Nagavani, A.V., Chandrika, V and Naidu, M.V.S. 2015. Productivity of finger millet as influenced by crop geometry and age of seedlings. Andhra Pradesh Journal of Agriculture Sciences. 1(3): 53-57.

Cheng, R.H and Liu, Z.L. 2003. Evolution of breeding objectives of foxtail millet and its developing tendency in China. Journal of Herbei Agricultural Sciences. 7: 95-98.

Crop Strategies and Contingency Plans for State of Telangana, 2015-16. PJTSAU, Hyderabad.

www.ac.in/hlfiles/2015/aug/crop\%20Str ategris.pdf.

Divya, S and Maurya, B.M. 2013. Response of kodo millet (Paspalum scrobiculatum) to varying levels of nitrogen under rain fed condition. International Journal of Scientific Research. 2(8): 10-11.

Dubey, O.P., Upadhyaya, S.P. and Chourasia, S.K. 1993. Effect of sowing date and plant spacing on kodo millet (Panicum scrobiculatum). Indian Journal of Agronomy. 38(1): 160-162.

Hariprasanna, K.2016. Foxtail MilletNutritional importance and cultivation aspects. Indian Farming. 65(12): 25-29.

Intodia, S.K. 1994. Response of foxtail millet (Setaria italica) genotypes to levels of nitrogen and phosphorous under rain fed conditions. Indian Journal of Agronomy. 64: 861-862.

Mahendra Singh, Mahendra Pal and Koushik, S.K. 1975. Effect of dates of sowing on grain yield of sorghum. Indian Journal of Agronomy. 20 (2): 103-105.

Munirathnam, P., Reddy, A., Sambasiva and Sawadhkar, S.M. 2006. Evaluation of foxtail millet varieties under low fertility conditions. Agricultural Science Digest. 26 (3): 197-199.
Navya Jyothi, K., Sumathi, V., Sunitha, N and Ravindra Reddy, B. 2015. Response of foxtail millet (Setaria italica L.) varieties to different levels of Nitrogen. Andhra Pradesh Journal of Agriculture Sciences. 1(3): 40-43.

Prathima, T., Shobha Rani, P., Naga Madhuri K.V and Latha P. 2015. Influence of sowing date on yield and yield components of bajra in rain fed alfisols of Andhra Pradesh. Andhra Pradesh Journal of Agricultural Sciences. 1(3):135-137.

Raghavendra, B and Halikatti, S.I. 1998. Response of little millet (Panicum milliare Lam.) varieties to nitrogen levels. Karnataka Journal of Agricultural Sciences. 11(1): 192-194.

Revathi, T., Sree Rekha, M., Venkata Lakshmi, N and Jaya Lalitha K. 2017. Growing degree days and heat use efficiency of finger millet varieties at different sowing dates. Andhra Pradesh Journal of Agricultural Sciences. 64 (2):289-294.

Saini, J. P and Thakur, S.R. 1997. Effect of variety and nitrogen on growth and yield of little millet (Panicum milliare) under dry temperate condition. Indian Journal of Agricultural Sciences. 67(7): 311-313.

Saini, J.P and Negi, S.C. 1996. Response of foxtail millet (Setaria italica) genotypes to nitrogen fertilization under drytemperate conditions. Indian Journal of Agronomy. 41(2): 261-264.

Sateesh, P.V. 2010. Millets: Future of food and farming. Eternal Bhoomi for earth conscious and sustainable living. http://www.bhoomimagazine.org/article /millets-future-food-and-farming.

Status Paper on Coarse Cereals. Directorate of Millets Development, Department of Agriculture and Cooperation, Ministry of Agriculture, GOI, 2014. 100-114. 
Umashankar Lal, S. 1982. Response of pearl millet hybrids to dates of sowing under rain fed condition. Indian Journal of Agronomy. 27(2): 137-139.

Upadhyay, P.N, Dixit, A.G., Patel, J.R and Chavda, J.R. 2001. Response of summer pearl millet (Pennisetum glaucum) to time and method of planting, age of seedling and phosphorous grown on loamy sand soils of Gujarat. Indian Journal of Agronomy. 46(1): 126-130.

\section{How to cite this article:}

Srikanya, B., P. Revathi, M. Malla Reddy and Chandrashaker, K. 2020. Effect of Sowing Dates on Growth and Yield of Foxtail Millet (Setaria italica L.) Varieties. Int.J.Curr.Microbiol.App.Sci. 9(04): 3243-3251. doi: https://doi.org/10.20546/ijcmas.2020.904.377 